\title{
Long-term container throughput forecast and equipment planning: the case of Bangkok Port
}

\author{
Veerachai Gosasang
}

Port Authority of Thailand, Bangkok, Thailand

\author{
Tsz Leung Yip
}

Department of Logistics and Maritime Studies, Hong Kong Polytechnic University, Hong Kong, and

Watcharavee Chandraprakaikul

University of the Thai Chamber of Commerce, Bangkok, Thailand

\begin{abstract}
Purpose - This paper aims to forecast inbound and outbound container throughput for Bangkok Port to 2041 and uses the results to inform the future planning and management of the port's container terminal.

Design/methodology/approach - The data used cover a period of 16 years (192 months of observations). Data sources include the Bank of Thailand and the Energy Policy and Planning Office. Causeand-effect forecasting is adopted for predicting future container throughput by using a vector error correction model (VECM).

Findings - Forecasting future container throughput in Bangkok Port will benefit port planning. Various economic factors affect the volume of both inbound and outbound containers through the port. Three cases (scenarios) of container terminal expansion are analyzed and assessed, on the basis of which an optimal scenario is identified.

Research limitations/implications - The economic characteristics of Thailand differ from those of other countries/jurisdictions, such as the USA, the EU, Japan, China, Malaysia and Indonesia, and optimal terminal expansion scenarios may therefore differ from that identified in this study. In addition, six particular countries/jurisdictions are the dominant trading partners of Thailand, but these main trading partners may change in the future.

Originality/value - There are only two major projects that have forecast container throughput volumes for Bangkok Port. The first project, by the Japan International Cooperation Agency, applied both the trend of cargo volumes and the relationship of volumes with economic indices such as population and gross domestic product. The second project, by the Port Authority of Thailand, applied a moving average method to forecast the number of containers. Other authors have used time-series forecasting. Here, the authors apply a VECM to forecast the future container throughput of Bangkok Port.
\end{abstract}

Keywords Forecasting, VECM, Cause-and-effect forecasting, Container throughput, Terminal layout

Paper type Case study

(C) Pacific Star Group Educational Foundation.

The first author expresses great gratitude to his $\mathrm{PhD}$ supervisor Dr Watcharavee Chandraprakaikul (Assistant Professor) and his host supervisor Dr Tsz Leung Yip (Associate Professor) for their patient guidance and assistance. This research was partially supported by the Hong Kong Polytechnic University (Grant No. G-YZ1P).

Equipment planning 
MABR

3,1

\section{Introduction}

Maritime transportation is an extremely important component of international trade. This transportation method is composed of maritime shipping and ports, which are key elements for creating economic growth (UNCTAD, 2016). Container transportation directly affects the international economy, especially in a country such as Thailand, for which seaborne trade dominates the transportation sector of imports and exports.

Container terminals are an interface between sea and land and are used to transship cargo containers between different transport vehicles for onward transportation. In export flow, containers are transported into the terminal from the hinterland by trucks, rail and barges and are subsequently loaded onto ships. In import flow, the process is reversed, but the time spent by containers in the container yard is longer owing to the unpredictability of when customers will pick up the containers (Wiese et al., 2011).

The economy of a port's hinterland directly affects maritime transportation. An expanding economy has a significant positive impact on the utilization of a container terminal. At present, many container terminals around the world have become very highly utilized as a consequence of the increasing growth in the container shipping industry.

In Thailand, the high utilization of the Bangkok Port container terminal has led to delays and congestion with regard to importation operations. Therefore, the Bangkok Port Authority is planning to expand the capacity of the container terminal. The basic factors influencing terminal expansion are terminal layout and equipment; however, for such changes to take place, annual container throughput must be considered. The modification of terminal layouts involves both width and length dimensions (Niwari, 2004).

A forecast of the volumes of import and export containers is the most important input into the planning and the operation of the Bangkok Port Authority and government offices. The results of forecasting container throughputs will be used to assist and plan the port operations, which include building new container terminals; formulating and executing operational plans and marketing strategies; and developing and improving financial and accounting processes. The management of a container terminal must develop mechanisms for measuring productivity and for increasing productivity without high financial investments (Beskovnik, 2008).

This paper investigates some feasible options for expanding an existing container terminal. Several alternatives for the expansion are identified, and therefore, a comparative assessment is conducted for the proposals, from both an operational viewpoint and a financial analysis perspective. An analysis of costs for container operations is an important part of such an assessment. Through this assessment, we identify which cost-acceptable expansion will generate the highest benefit for the Bangkok Port Authority.

The structure of this paper is organized as follows: Section 2 reviews the relevant literature, Section 3 presents the research methodology, Section 4 presents the results and a discussion of the findings, Section 5 presents an application of forecasting for port planning in the case of Bangkok Port and Section 6 provides the conclusions of the study.

\section{Literature review}

The review is devoted to the literature on forecasting techniques, maritime forecasting and terminal management.

\section{Forecasting techniques and Maritime forecasting}

Forecasting is a method or technique used for estimating many future aspects of a business or other operations. Here, we consider only the cause-and-effect model of econometric forecasting (Armstrong, 2001). The cause-and-effect model assumes that the variable to be 
forecasted can be estimated by the explanatory relationship with one or more independent variables. The purpose of this model is to discover the form of the relationship and to forecast the values of dependent variables in the future (Makridakis et al., 1998).

Econometric methods are most useful when strong causal relationships with sales or other entities are expected, when causal relationships are known or can be estimated and when large changes are expected to occur in the causal variables over the forecast horizon and can be accurately forecast or controlled, especially with respect to their direction (Armstrong and Brodie, 1999; Allen and Fildes, 2001). A vector error correction model

(VECM) is characterized by having a dynamical system in which the deviation of the current state from its long-run relationship is fed into its short-run dynamics. It is included in the category of multiple time-series models that directly estimate the maximum speed of a dependent variable $(\mathrm{Y})$ and its return to equilibrium after a change in an independent variable. Such models are useful when dealing with co-integrated data but can also be used with stationary data.

Various researchers have investigated aspects of maritime forecasting. Chou et al. (2008) showed the importance of the non-stationary relationship between the volume of containers and macroeconomic variables. These authors used as factors in the regression analysis the volume of export containers, the volume of import containers, population, industrial production index, gross national product (GNP), GNP per capita, wholesale gross domestic product (GDP), agricultural GDP, industrial GDP and service GDP.

Peng and Chu (2009) suggested exploring other forecasting methods that apply the latest technologies, such as neural networks, artificial intelligence or advanced data-mining techniques, to predict container throughput volumes. Chen and Chen (2010) examined monthly data on container throughput volumes generated by three major ports in Taiwan (Keelung, Taichung and Kaohsiung ports) between 1978 and 2006. Three models for predicting container throughput were proposed, namely, genetic programming, the decomposition approach and SARIMA. The genetic programming approach produced good results compared with the other two methods, giving a lower mean absolute percentage error.

Fung (2002) applied a VECM to forecast the demand for Hong Kong container-handling services and to forecast the nature of the interaction between major ports in East and Southeast Asia. Hui et al. (2004) applied a different approach for studying the Port of Hong Kong's container throughput, proposing an econometric model and correcting it by using a VECM.

A VECM achieves higher degrees of accuracy compared with the original econometric models. Another example of a VECM is that of Syafi'I (2006), who applied a multivariate autoregressive model to the case of Indonesia. Syafi'I checked the stationarity of the data and the order of integration by using the augmented Dickey-Fuller test. He also used the Johansen approach to find the co-integration relationship between parameters by using the VECM, which resulted in a reasonable forecast of container throughput.

\section{Terminal management}

The basic function of a container terminal is the transfer and storage of containers. Terminal operators are accordingly concerned with maximizing operational productivity, as containers are handled at the berth and in the marshalling yards, and with efficiently using available ground space. From an operational perspective, the port terminal itself can also be considered to be a chain consisting of consecutive links (i.e. ship unloading, storage transport, storage, loading transport and loading containers that are inland bound) (Zondag et al., 2010). 
MABR

3,1

Seo and Park (2016) made estimates of the minimum efficient scale of the port industry and reported the minimum efficient scale for Korean ports to be 753,000 twenty-foot equivalent units (TEUs). They suggested that larger plants are likely to be more efficient than smaller plants in a port terminal.

Yard layout influences terminal production because the stacking position of a container determines its transportation distance to or from the quay. The layout of the yard needs to be configured to support a high rate of throughput and is optimal when the total time it takes to get containers to and from the quay is minimal (Putten, 2005). There are two different types of yard layout. The first is defined according to the position in which storage blocks are laid out in a yard using the quay line as parallel, and the second is defined according to the position in which storage blocks are laid out in a yard in a perpendicular manner.

Regarding yard layout, much research has stated that the yard layout of container terminals is highly dependent on container throughput and container storage. HolguínVeras and Jara-Díaz (2006) developed an approach for determining space allocation and prices for priority systems in container yards, while Petering and Murty (2009) studied quay crane rate and the length of storage blocks in the container yard. Petering (2009) investigated the relationship between the width of the storage blocks in a terminal's container yard and the type and positioning of yard equipment. Wiese et al. (2011) introduced an integer linear program for planning the layout of container yards, focusing on terminal layout planning. The decisions about terminal capacity and the types of equipment used influence the design of a terminal layout. In the final example of yard layout research, Kemme (2012) investigated the effect of strategic decisions on both the crane system and the layout of yard blocks.

Other research has focused on yard-handling equipment, which is another factor affecting terminal design. Because different types of yard equipment affect yard layouts and stacking heights, the main yard facilities therefore include the chassis system, straddle carrier and yard gantry cranes. Those papers focused on rubber-tyred gantry cranes (RTGCs) and rail-mounted gantry cranes (RMGCs) (Agerschou and Lundgren, 1993).

Yard cranes are considered in this paper, including the RTGC $4+1$, the RTGC $6+1$ and the RMGC $6+1$. All of them have one-over-four stacking capabilities. The basic RTGC design is largely standardized; it is space-efficient, fast in operation and offers scope for advanced automation. Because the RTGC does not follow a fixed rail track, it offers a more flexible operation compared with other types (Anonym, 1996; Atkins, 1993; Avery, 1999). RMGCs travel on a fixed rail track with cantilevers outside the portals of the cranes. There is no interchange area required in a fully RMGC system (Anonym, 1996).

Many studies have investigated the role of equipment in terminal capacity and efficiency. Chu and Huang (2005) presented a comparison of different container-handling systems with regard to a terminal's capacity. The approach aimed to support decisions regarding terminal planning with respect to the design of a terminal and the used handling equipment. $\mathrm{Ng}$ and Mak (2005) studied the problem of scheduling multiple yard cranes to handle jobs with different "ready" times within a yard zone. Guo et al. (2011) presented two new algorithms to efficiently compute yard crane dispatching sequences that are provably optimal within the planning window. As the last example, Speer et al. (2011) applied automated stacking cranes as forming the heart of modern container terminals. Overall, those various studies show that the productivity of handling equipment and systems has a major influence on the performance of the terminal.

Financial analysis should be performed to decide whether a cost-acceptable expansion would generate the highest reward for the container terminal. The decision-making process for choosing a container-handling system can be divided into two stages: 
(1) Determine the container yard sizes and decide what handling equipment types and handling capabilities meet the demand of the annual container throughput.

(2) Make a cost comparison between these different handling systems to discover which is the least costly.

\section{Research methodology}

Forecasting methodology

The forecasting methodology used in the present study incorporated the following four steps.

(1) Qualifying the economic factors: Three rounds of Delphi were applied for the qualification of factors.

(2) Collecting data: The data constituted dependent factors for the period of 2000-2015 (number of inbound and outbound containers in Bangkok Port) and independent factors for the same period. The selected independent factors affecting imported (inbound) container throughput were economic growth rate, interest rate, inflation rate, exchange rate, population, manufacturing production index (MPI) and the trade value of imports. The selected independent factors affecting exported (outbound) containers were consumer price index (IPI), population, exchange rate, fuel price, MPI, the trade value of exports, the trade value of imports, economic growth rate and industrial production index (IPI). The data covered a 16-year period (192 months or 192 observations). The data were sourced from the Bank of Thailand (2016), the Office of the National Economic and Social Development Board (2016), the World Bank (2016), the Ministry of the Interior, and the Energy Policy and Planning Office (2016).

(3) Choosing the correct-fit model; cause-and-effect: The purpose of this model was to discover the form of the relationship between economic factors and the throughput (number) of containers. We applied a VECM for forecasting inbound and outbound container throughput at Bangkok Port.

(4) Evaluating the forecasting model: We considered three accuracy evaluations/ measures for VECM forecasting. They were the mean absolute error (MAE), root mean squared error (RMSE) and mean absolute percentage error (MAPE), which are defined, respectively, in equations (1)-(3):

$$
\begin{aligned}
M E A & =\frac{\sum_{\mathrm{i}=1}^{n}\left|y_{i}-\hat{y}_{i}\right|}{n} \\
R M S E & =\sqrt{\frac{\sum_{\mathrm{i}=1}^{n}\left(y_{i}-\hat{y}_{i}\right)^{2}}{n}} \\
\text { MAPE } & =\frac{\sum_{\mathrm{t}=1}^{n}\left|e_{t} / Y_{t}\right|}{n} \times 100
\end{aligned}
$$


MABR

3,1

58

\section{Container terminal expansion}

The yard capacity was measured as the total TEU visits. The factors affecting terminal capacity include the number of terminal ground slots (TGSs), the average dwell time (the number of days over which containers are stored in the terminal), peak factor (a factor that represents the highest volume of container throughput that might be realized by the terminal), stacking height (how high the containers are stacked for each type of container) and stacking density (how intensely the container yard is being utilized) (Wiegmans, 2003).

In addition, the main factors for expansion of the container terminal were considered, including the current situation of the terminal and yard capacity, capacity requirements, possible expansion alternatives, the equipment and layout for each alternative, the financial analysis for each alternative and an overall analysis of all alternatives.

\section{Financial analysis}

Terminal expansion usually requires a lump-sum investment to be made by the terminal owners. Therefore, a reliable prediction of both costs and revenues should be performed before a final decision is taken regarding expansion. Meermans and Dekker (2001) emphasized that the huge investment costs required to expand a terminal would increase productivity and lead to large cost savings for the terminal operator.

Various criteria exist for forecasting the future performance of terminals. The most commonly used are net present value (NPV), return on investment (ROI) and payback period, all of which are applied in this paper. The internal rate of return (IRR) method is often used together with NPV as both are based on the same principle. IRR is the rate that equates the present gross value of a project with the capital outlay associated with the investment opportunity. IRR is the rate of return used in capital budgeting to measure and compare the profitability of investments. IRR is a discount rate that makes the NPV of all cash flows from a particular project equal to zero [equation (4)]:

$$
\sum_{t=o}^{n} \frac{C_{t}}{(1+r)^{t}}=\sum_{t=o}^{n} \frac{B_{t}}{(1+r)^{t}}
$$

NPV is the difference between the present value of cash inflows and the present value of cash outflows. NPV is used in capital budgeting to analyze the profitability of a projected investment [equation (5)]:

$$
N P V=\sum_{t=1}^{T} \frac{X_{t}}{(1+I R R)^{t}}-Y=0
$$

where:

$$
\begin{aligned}
& \mathrm{NPV}=\text { net present value [Baht]; } \\
& \mathrm{T} \text { = time horizon [years]; } \\
& \mathrm{X}_{\mathrm{t}}=\text { operating cash flow at year t [Baht]; } \\
& \mathrm{Y} \text { = initial investment (capital outlay) [Baht]; and } \\
& \mathrm{IRR}=\text { internal rate of return [per cent]. }
\end{aligned}
$$

ROI is a performance measure used to evaluate the efficiency of an investment or to compare the efficiencies of a number of different investments. ROI measures the amount of return on an investment relative to the investment's cost. The ROI method is often favored when making managerial decisions as it is easy to understand. A high ROI means that the 
company will achieve a high return when investing in a project. However, the net income of the company is not always a reliable measure of financial performance. Therefore, ROI may not always accurately gauge the overall success of an investment (Mills, 1994). ROI is calculated as:

$$
R O I_{t}=\frac{N I_{t}}{I n v_{t}}
$$

where:

$\mathrm{ROI}_{\mathrm{t}}=$ return on investment in year $\mathrm{t}[$ Baht $]$;

$\mathrm{NI}_{\mathrm{t}}=$ net income after tax in year $\mathrm{t}[\mathrm{Baht}] ;$ and

$\mathrm{Inv}_{\mathrm{t}}=$ investment in year $\mathrm{t}$ [Baht].

Benefit cost analysis (BCA) estimates and summates the equivalent monetary value of the benefits (B) and costs (C) to the community of projects to establish whether they are worthwhile:

$$
\bar{B}=\frac{B_{0}+\frac{B_{1}}{(1+r)}+\frac{B_{2}}{(1+r)^{2}}+\ldots+\frac{B_{n}}{(1+r)^{n}}}{C_{0}+\frac{C_{1}}{(1+r)}+\frac{C_{2}}{(1+r)^{2}}+\ldots+\frac{C_{n}}{(1+r)^{n}}}
$$

Payback period is the length of time required to recover the cost of an investment. The payback period of a given investment or project is an important determinant of whether to undertake the position or project, as longer payback periods are typically not desirable for investment positions. The payback period is a very important investment criterion, as it reflects the way in which the investment is paid back by the cash inflows that accumulate over time:

$$
\text { Paybackperiod }=\frac{\text { Cost of Investment }}{\text { Annual Cash Flow }}
$$

\section{Results of forecasting using the vector error correction model}

We used a VECM as described above to forecast the numbers of inbound and outbound containers. The results of the forecasting are presented in Figure 1 and Table I. The characteristics of both imported and exported containers are as follows: importing 57.3 per cent, including FCL (full container load) boxes, 79.4 per cent (laden 96.9 per cent, refer 3.1 per cent); LCL (less than container load) boxes, 17.2 per cent; and empty boxes, 3.4 per cent; and exporting 42.7 per cent, including FCL, 77.9 per cent (laden 96.9 per cent, refer 3.1 per cent); LCL, 13.2 per cent; and empty boxes, 2.9 per cent. The forecasting accuracies as given by MAE, RMSE and MAPE (Table II) show that the VECM estimates are satisfactory.

The results of the forecasting will assist officers at Bangkok Port to deal with the future number of inbound and outbound containers, as well as to engage in yard planning, management and future revenue generation. The estimated throughput and expansion should make a valuable contribution to the economy, including facilitating both direct and indirect shipments.

This paper contributes to the literature by using a forecasting technique (a VECM) that provides the most accurate prediction of the volumes of both inbound and outbound containers through Bangkok Port. Many previous studies have forecasted 


\section{MABR}

3,1

60

Figure 1.

Forecast of inbound and outbound container throughput for the period of 2017 2041 (unit: TEUs)

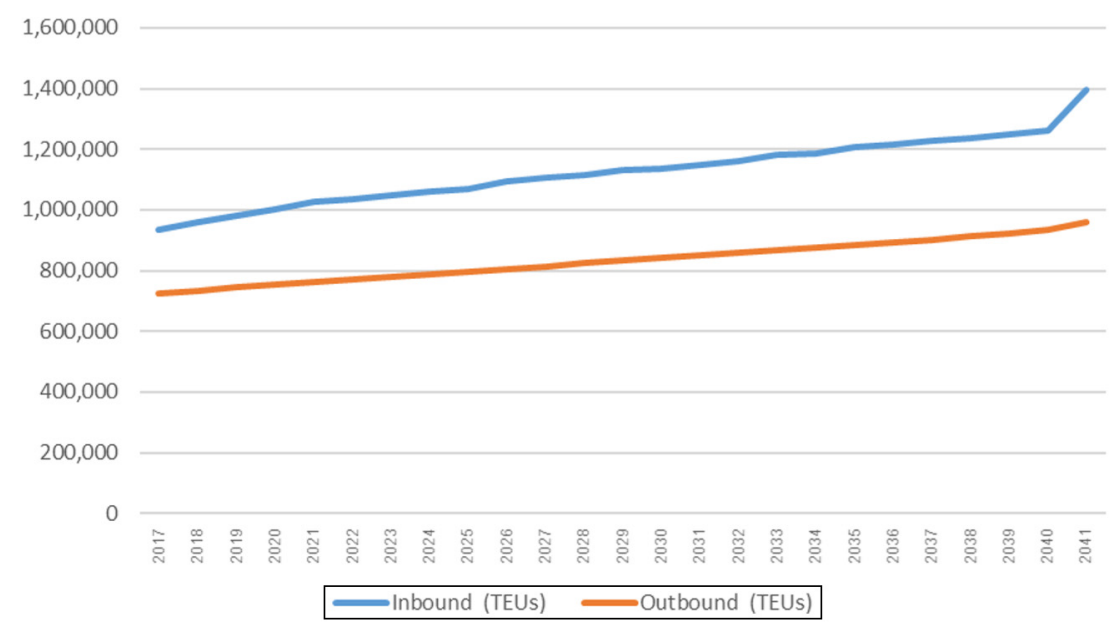

\begin{tabular}{lcc}
\hline Year & Inbound (TEUs) & Outbound (TEUs) \\
\hline 2017 & 935,726 & 726,207 \\
2018 & 958,195 & 735,049 \\
2019 & 980,663 & 743,891 \\
2020 & $1,003,132$ & 752,732 \\
2021 & $1,025,600$ & 761,574 \\
2022 & $1,034,151$ & 770,415 \\
2023 & $1,047,865$ & 779,257 \\
2024 & $1,061,519$ & 788,099 \\
2025 & $1,070,539$ & 796,940 \\
2026 & $1,093,005$ & 805,782 \\
2027 & $1,105,399$ & 814,623 \\
2028 & $1,115,436$ & 823,465 \\
2029 & $1,130,451$ & 832,306 \\
2030 & $1,137,943$ & 841,148 \\
2031 & $1,148,193$ & 849,990 \\
2032 & $1,160,413$ & 858,831 \\
2033 & $1,182,880$ & 867,673 \\
2034 & $1,188,343$ & 876,514 \\
2035 & $1,205,349$ & 885,356 \\
2036 & $1,217,491$ & 894,198 \\
2037 & $1,227,817$ & 903,039 \\
2038 & $1,237,489$ & 911,881 \\
2039 & $1,248,237$ & 920,722 \\
2040 & $1,262,148$ & 934,646 \\
2041 & $1,396,326$ & 958,224 \\
\hline
\end{tabular}

container numbers by using time-series forecasting or cause-and-effect forecasting (Gosasang et al., 2011). These studies concluded that time-series forecasting does not specify relationships among factors, and that linear regression may produce spurious results if non-stationary data exist. VECMs and neural network methods are suitable 
for non-stationary data. The advantage of a VECM is that it can be used for testing the presence of the co-integration relationship among several non-stationary variables (Moniruzzaman et al., 2011). The disadvantage of the neural network method is that it is complex with no standard software implementations, as well as its "black box" nature, its greater computational burden and its proneness to overfitting. This leaves users to choose from a wide variety of parameters, including the input vector and the non-linear transformation function, as well as elements defining the optimization routines (Adya and Collopy, 1998).

\section{The application of forecasting to port planning: the case of Bangkok Port}

Many container terminals worldwide have become excessively utilized. The expansion of the terminal area will improve the overall productivity of Bangkok Port. The building of capacity on the existing operating area might be the most suitable location for this terminal expansion. Terminal expansion is an option for adding capacity and improving the productivity of a terminal, and a better design of yard capacity and yard cranes is the best way to achieve such terminal expansion. This section explores the current capacity of Bangkok Port and various alternatives for the future expansion of the port's terminal.

\section{Calculating the current yard capacity in Bangkok Port}

Bangkok Port consists of two terminals: Terminal 1 (24 acres, east) and Terminal 2 (12 acres, west). Yard capacity is measured in terms of the total TEU visits and is calculated as:

$$
\text { TEU Visitsper annum }=\frac{T G S \times \text { Stacking Density } \times \text { Stacking Height } \times 365(\text { days })}{\text { Dwell Time }(\text { days }) \times \text { PeakFactor }}
$$

The results of yard capacity for the two terminals are given in Table III.

\begin{tabular}{lcc}
\hline Item & Inbound containers & Outbound containers \\
\hline MAE & 4,012 & 3,312 \\
RMSE & 5,358 & 4,302 \\
MAPE & 6 & 8 \\
Total number of observations & 180 & 180 \\
\hline
\end{tabular}

Table II. Performance of forecasting the numbers of inbound and outbound containers

\begin{tabular}{lcccr}
\hline & \multicolumn{2}{c}{ Inbound zone } & \multicolumn{2}{c}{ Outbound zone } \\
Capacity & Terminal 1 & Terminal 2 & Terminal 1 & Terminal 2 \\
\hline TGS $\times$ stacking height [TEUs] & 8,050 & 4,800 & 4,538 & 3,834 \\
TEU throughput per annum & 379,129 & 226,064 & 213,725 & 180,560
\end{tabular}

Notes: Calculations were performed using equation (9); stacking density $=0.8$; dwell time $=5$ days; peak factor $=1.24$

Table III.

Yard capacity, measured in TEUs 
MABR

3,1

\section{2}

Table IV.

Summary of capacity in the three proposed cases for inbound containers, measured in TEUs
The expansion of yard capacity at Bangkok Port

Bangkok Port is the main single-river port in Thailand and benefits from its advantageous geographical location in the center of the capital city (Bangkok), being surrounded by factories and manufacturing facilities. Bangkok Port is a convenient gateway for shippers because of its accessibility and, therefore, the capacity to lower logistics costs.

Bangkok Port's infrastructure needs to be expanded to cater for the forecast demand of about 1.7 million TEUs per annum by around 2040 (FCLs only). Expansion of the container terminal at the port will ensure that the needs of the stakeholders will be served, as well as those of the port customers, with the latter presently suffering from the current limited capacity of the container terminal and from delays caused from port congestion. The objectives of the expansion are increased container throughput, more efficient container handling, a more efficient terminal layout, more reliable services, more competition between container terminals and an increased capacity for international trading.

The capacity expansion for the container terminal includes an increase in lane width and an increase in the use of high stacking. The lane widths include $4+1$ (four rows of container stacking and one lane for trucks' passage) and $6+1$ (six rows of container stacking and one lane for trucks' passage). The stacking height is four stacks. Yard cranes used include RTGCs $4+1$, RTGCs $6+1$ and RMGCs $6+1$, with all of these being one-over-four stacking (four stacks in height with one container that can be moved over the stack). Below, we conduct an analysis to decide which cost-acceptable expansion is most likely to generate the greatest benefit to the container terminal.

\section{Three proposed models for the inbound and outbound zones}

The number of ground slots will influence container throughput, as will the average dwell time of the containers, the peak factor, the stacking height and the stacking density of the storage yard (Yip et al., 2011). The volume of container throughput will influence the yard layout and the yard equipment used (Li and Yip, 2013).

Several assumptions were made for the import (inbound) zone and the export (outbound) zone. The calculations were based on the assumptions that at full usage of the terminal capacity, the terminal has a maximum container yard, a peak factor of 1.24 , an average dwell time for containers of five days and a stacking yard capacity of 80 per cent. Fuel consumption and power consumption are related to the total volume and the number of reefer containers, empty containers and LCLs, which are not included in all scenarios.

The scope of this paper is an expansion of capacity based only on the restructuring of existing spaces rather than on building new terminals. The scenarios for the inbound and outbound zones are presented in turn below.

Inbound zone. Three alternatives are proposed for the inbound zone, as follows, with the results being reported in Table IV.

\begin{tabular}{lccc}
\hline Capacity & Case 1 RTGC $4+1$ and RTGC 6 +1 & Case 2 RTGC 6 +1 & Case 3 RMGC \\
\hline Terminal 1 capacity & 12,176 & 14,472 & 14,472 \\
Terminal 2 capacity & 6,576 & 6,576 & 6,576 \\
Total capacity & 18,752 & 21,048 & 21,048 \\
TEU throughput & 883,159 & 991,293 & 991,293
\end{tabular}

Notes: Calculations made using equation (9); stacking density $=0.8$; dwell time $=5$ days; peak factor $=$ 1.24 
Case 1: current layout with one-over-four stacking applied.

This model used RTGC $4+1$ and RTGC $6+1$ equipment. RTGCs are often used in large and very large terminals. The RTGC system provides a very high stacking density because of the high stacking capability of the cranes and block stacking. RTGCs $4+1$ are applied for the tracks with four widths for container stacking and one lane for trucks' passage. RTGC $6+1$ is applied for the tracks with six widths for container stacking and one lane for trucks' passage. Stacking is one-over-four.

Case 2: RTGC $6+1$, one-over-four stacking.

This model applied RTGC $6+1$ equipment. The RTGC system gives a very high stacking density because of the high stacking capability of the cranes and block stacking. RTGC $6+1$ is applied for the tracks with six widths for container stacking and one lane for trucks' passage. Stacking is one-over-four.

Case 3: RMGC $6+1$, one-over-four stacking.

This model applied RMGC $6+1$ equipment. RMGCs travel on fixed rail tracks with a cantilever outside the portal of the cranes. There is no interchange area required in a full RMGC system. Stacking is one-over-four.

Outbound zone. Three alternatives are proposed for the outbound zone, as follows, with the results being reported in Table $\mathrm{V}$.

Case 1: RTGC $4+1$, one-over-four stacking.

This model applied RTGC $4+1$ equipment. RTGC $4+1$ is applied for the tracks that are four widths and with one lane for trucks. Stacking is one-over-four.

Case 2: RTGC $6+1$, one-over-four stacking.

This model applied RTGC $6+1$ equipment. RTGC $6+1$ is applied for the tracks that are six widths and with one lane for trucks. Stacking is one-over-four.

Case 3: RMGC $6+1$, one-over-four stacking.

This model applied RMGC $6+1$ equipment. RMGCs travel on a fixed rail track with a cantilever outside the portal of the cranes. There is no interchange area required in a full RMGC system.

\section{Financial analysis}

This section includes consideration of procurement costs, container yard development costs, consumption and maintenance costs, wages and salaries and revenues. The values for the parameters of financial analysis (NPV, IRR, ROI and the payback period) are summarized in Table VI (inbound zone) and Table VII (outbound zone). A summary of the financial analysis is given in Table VIII.

Terminal expansion usually requires a lump-sum investment. An accurate prediction of both cost and revenue analysis should be performed before the final investment decision is taken.

\begin{tabular}{lccc}
\hline Terminal & Case 1 RTGC $4+1$ & Case 2 RTGC $6+1$ & Case 3 RMGC $6+1$ \\
\hline Terminal 1 capacity & 7,680 & 8,640 & 8,640 \\
Terminal 2 capacity & 7,680 & 8,640 & 8,640 \\
Total capacity & 15,360 & 17,280 & 17,280 \\
TEU throughput & 542,555 & 596,810 & 596,810
\end{tabular}

Notes: Calculations were performed using equation (9); stacking density $=0.8$; dwell time $=5$ days; peak factor $=1.24$

Equipment planning 
MABR

3,1
Parameter

Stacking [number of stacks]

Block [TEUs]

Annual yard capacity [TEUs]

\section{4}

Compare to current capacity [TEUs]

Forecasting inbound containers in 2039 [TEUs]

Total container yard development cost [Baht]

Table VI.

Total equipment cost [Baht]

Parameters of comparisons for the inbound zone
Total wages and salaries [Baht]

Total maintenance cost [Baht]

Total fuel and power [Baht]

Total cost [Baht]
Case 1 RTGC $4+1$ and RTGC $6+1$ Case 2 RTGC $6+1$ Case 3 RMGC

$\begin{array}{rrr}4 & 4 & 4 \\ 18,752 & 21,048 & 21,048 \\ 883,159 & 991,293 & 991,293 \\ +210,735 & +318,839 & +318,839 \\ 991,100 & 991,100 & 991,100 \\ 620,057,643 & 597,407,236 & 511,647,356 \\ 1,363,600,000 & 1,632,400,000 & 3,040,000,000 \\ 12,715,104,179 & 12,715,104,179 & 12,715,104,179 \\ 396,529,449 & 396,529,449 & 408,374,680 \\ 1,271,981,074 & 1,271,981,074 & 661,527,509 \\ 16,327,030,303 & 16,574,023,655 & 17,336,629,570 \\ \end{array}$

\section{Table VII.}

Parameters of comparisons for the outbound zone

\section{Parameter}

Stacking [number of stacks]

Block [TEUs]

Annual yard capacity [TEUs]

Compared to current capacity [TEUs]

Forecasting inbound containers in 2039 [TEUs]

Total container yard development cost [Baht]

Total equipment cost [Baht]

Total wages and salaries [Baht]

Total maintenance cost [Baht]

Total fuel or power [Baht]

Total cost [Baht]
Case 1 RTGC $4+1 \quad$ Case 2 RTGC $6+1 \quad$ Case 3 RMGC

\begin{tabular}{rrr}
4 & 4 & 4 \\
15,360 & 17,280 & 17,280 \\
723,406 & 813,832 & 813,832 \\
$+329,121$ & $+419,547$ & $+419,547$ \\
717,243 & 717,243 & 717,243 \\
$474,424,800$ & $458,856,600$ & $484,395,000$ \\
$779,200,000$ & $699,600,000$ & $960,000,000$ \\
$12,715,104,179$ & $12,715,104,179$ & $12,715,104,179$ \\
$290,008,624$ & $290,008,624$ & $298,684,344$ \\
$928,353,624$ & $928,353,624$ & $482,773,882$ \\
$15,187,090,946$ & $15,091,922,746$ & $14,898,957,405$ \\
\hline
\end{tabular}

\begin{tabular}{lccc}
\hline Parameter & Case 1 & Case 2 & Case 3 \\
\hline Average ROI & $146.2 \%$ & $145.02 \%$ & $140.03 \%$ \\
IRR & $10.36 \%$ & $10.30 \%$ & $10.10 \%$ \\
NPV & Baht $6.52 \mathrm{bn}$ & Baht $6.39 \mathrm{bn}$ & Baht $5.89 \mathrm{bn}$ \\
CBA & 3.00 & 2.99 & 2.94 \\
Payback period & 9 years 3 months & 9 years 4 months & 9 years 5 months \\
\hline
\end{tabular}

Costs. The costs considered included the following:

- Construction costs: Container terminals require special types of pavements and roads to cope with the heavy and continuous loads of container-handling equipment, including yard hostlers and RTGCs. Typically, container terminals use either asphalt or concrete block pavement systems. The design of these structures has been based largely on motorway road technology.

- Yard crane costs: These are the costs of purchasing yard equipment such as RTGCs and RMGCs. The price used is taken from the most recent procurement of the Port Authority of Thailand. 
- Wages and salaries: These costs include wages and salaries, overtime payments and bonuses.

- Consumption and maintenance costs: these include fuel costs, lubrication costs, filter costs, spare part costs, tyre replacement costs and electrical maintenance for RTGCs and RMGCs.

Revenues. Revenues include container-handling revenues, container storage revenues and admission fees for vehicles:

(1) Container-handling revenues:

- Percentage share of 20-feet containers $=61.4$ per cent; and of 40-feet containers $=$ 38.6 per cent (for inbound containers)

- $\quad$ Percentage share of 20-feet containers $=66.4$ per cent; and of 40 -feet containers $=$ 33.6 per cent (for outbound containers)

- Container-handling charge for 20-feet containers $=$ Baht 1,550 per box

- Container-handling charge for 40-feet containers = Baht 2,650 per box

(2) Container storage Revenues:

Dwell time (the duration that containers are located in the terminal) = five days: the first three days are exempted and the next two days are charged as follows:

- Two days for a 20 -feet container $=$ Baht $160 \times 2=$ Baht 320

- Two days for a 40-feet container $=$ Baht $320 \times 2=$ Baht 640

(3) Admission fees for vehicles:

- Admission fee for a vehicle with a 20-feet container = Baht 100

- Admission fee for a vehicle with a 40-feet container $=$ Baht 200

With regard to the financial analysis applied to all scenarios (Table VIII), the best strategy for the terminal is Case 1, with an ROI of 146.2 per cent, an IRR of 10.36 per cent, an NPV of Baht $6.52 \mathrm{bn}$ and a payback period of nine years and three months.

\section{$\mathrm{CO}_{2}$ emissions}

A major challenge for container terminals is to improve the performance of their container operations. To satisfy the demands of shipping companies and to retain their competitive position, container terminals need to increase the handling speed of containerships and to minimize the operating costs. However, the climate change policies of port authorities are now challenging container terminals to reduce their greenhouse gas emissions. The main inventory of air pollutants attributable to port activities are those related to yard trucks and yard cranes. The concept of greener ports is becoming increasingly important for terminals because major companies are focusing on reducing the emissions from the container carriers and from container terminals that are handling their containers (Port of Rotterdam, 2014).

RTGCs in Bangkok Port are driven by diesel engines. These engines release high emissions of pollutants into the environment because of the large amount of fuel used during the cranes' operation. RMGCs are mounted on fixed rail tracks with a cantilever outside the portal of the cranes; these cranes produce lower emissions, have very low operating noise levels and have a degree of operational automation. Equation (10) was used to estimate $\mathrm{CO}_{2}$ emissions in tons per year for each of the three cases:

Emissions [tons per year] $=$ Annual hours $\times \mathrm{CO}_{2}$ emissions $[\mathrm{g} / \mathrm{kWh}] \times$ NetPower $[\mathrm{kW}]$ 
MABR

3,1

\section{6}

Bangkok Port uses Cummins engine model QSX 15-G 11 in its RTGCs (power $=333 \mathrm{~kW}$ at $1,500 \mathrm{rpm}$, category $\mathrm{H}$ and $\mathrm{CO}_{2}$ emission $=3.5 \mathrm{~g}$ ) (Table IX). The average hours of operation for RTGCs in Bangkok Port is $15 \mathrm{~h} /$ day.
$\mathrm{CO}_{2}$ Emissions per RTGC $=$ Annual Hours $\times \mathrm{CO}_{2}$ Emission $\times$ Net Power $=(15 \times 365) \mathrm{hrs} \times 3.5 \mathrm{~g} / \mathrm{kWh} \times 333 \mathrm{~kW}$ $=6,381,112.5 \mathrm{~g} /$ year $=6.38$ tons $/$ year

Case 1: 54 RTGCs $\times 6.38$ tons/year $=344.52$ tons/year

Case 2: 50 RTGCs $\times 6.38$ tons/year $=319.1$ tons/year

Case 3: There is no $\mathrm{CO}_{2}$ emission according to the EU (2004) Stage IIIA Emission Standard.

\section{Comparative assessment}

Three cases (scenarios) were examined, as mentioned above. Case 1 has excellent financial analysis results, with an ROI of 146.2 per cent and an NPV of Baht 6.523bn. However, it has an annual capacity that is lower than the forecast throughput of containers from 2028 onwards. There is a reduction of $\mathrm{CO}_{2}$ in Case 1 of 344.52 tons per year, brought about by using 54 units of RTGCs. In comparison, the ROI for Case 2 is 142.02 per cent and the NPV is Baht 6.387bn. The annual capacity for Case 2 exceeds the forecast number of containers until 2039. There is a total reduction of $\mathrm{CO}_{2}$ emissions for Case 2 , as a result of using 50 units of RTGCs, of 319.1 tons per year.

The advantage of RTGCs (in Cases 1 and 2) compared with RMGCs (in Case 3) is their flexibility, as RTGCs can move to other storage blocks, whereas RMGCs are fixed to the implemented rails. RTGCs are more flexible and more economical to purchase and install but are more expensive to operate than RMGCs. On the other hand, the advantage of RMGCs is that they are suitable for both port and rail terminals, are suitable for various yard space conditions, allow increased yard capacity with wider and higher stacking possibilities, give reductions in emissions and noise and have lower maintenance needs, lower energy demands and reduced running costs. The advantage of Case 3 is no emissions of $\mathrm{CO}_{2}$ and (in comparison with Case 1) an annual capacity that exceeds the forecast number of containers until 2039. However, the financial parameters are not as good as those for Cases 1 and 2.

\section{Conclusions}

One of the most important factors for developing port facilities and the infrastructure of a container terminal is predicting the volume of container throughput. Therefore, robust forecasting methods that can provide accurate values for future throughput volumes are

\begin{tabular}{llcc}
\cline { 2 - 3 } & Category (Stage IIIA) & Net power $[\mathrm{kW}]$ & $\mathrm{CO}_{2}[\mathrm{~g} / \mathrm{kWh}]$ \\
\cline { 2 - 4 } & $\mathrm{H}$ & $130 \leq \mathrm{P}<560$ & 3.5 \\
Table IX. & $\mathrm{I}$ & $75 \leq \mathrm{P}<130$ & 5.0 \\
Stage IIIA emission & $\mathrm{J}$ & $37 \leq \mathrm{P}<75$ & 5.0 \\
standard for non- & $\mathrm{K}$ & $19 \leq \mathrm{P}<37$ & 5.5 \\
road diesel engines & Source: EU (2004). European Emission Standards & \\
\hline
\end{tabular}


extremely important when making decisions regarding planning and managing a port such as Bangkok Port. Furthermore, with such information, the container terminal operators should be able to minimize the risk of making an under- or over-investment on the expansion project.

The present study made forecasts of both inbound and outbound container throughput for Bangkok Port by using cause-and-effect forecasting. A VECM was applied because it is a suitable tool for economic analysis and forecasting based on multivariate co-integrated time series characterized by non-stationary data.

Many container terminals have become over-utilized as a consequence of the increasing growth in the container shipping industry during the past decade. Increasing vessel sizes have also impacted container terminal utilization (Port of Rotterdam, 2014). Ports need to enhance capacity to keep up with and anticipate the rising demand. In Thailand, such expansion is constrained by a limited supply of available land, especially for urban center ports, as well as escalating environmental concerns by various stakeholders.

An improvement in the productivity of a terminal will increase container throughput. The size of the container terminal and associated factors (e.g. yard layout and equipment types used) is one of the basic aspects that needs to be analyzed when planning the development of a container port. However, this is an extremely challenging process for terminal operators and port authorities. In the present study, we re-provisioned the yard layout for Bangkok Port according to forecasted container throughput volumes. Both types of cranes, namely, RTGCs and RMGCs, were considered in the modeling. The results of the re-provisioning are an increase in annual container throughput volumes, an improvement in the efficiency of terminal operation and increased future revenues that will help pay back the financial investment made in the expansion of the terminal.

Various investment criteria were applied in the study to ensure that the financial resources being invested in the terminal expansion will bring about the best result in the future. These criteria were NPV, IRR, the average ROI, BCA and the payback period.

The concept of the green port is becoming more important for terminals, as many companies are focusing on reducing the emissions that result from their container transportation. Bangkok is also interested in the green port concept, so it can protect the community from negative port impacts, distinguish the port as an environmental leader, reduce harmful air emissions from port activities and promote sustainability.

\section{References}

Adya, M. and Collopy, F. (1998), "How effective are neural networks at forecasting and prediction? A review and evaluation", Journal of Forecasting, Vol. 17 Nos 5/6, pp. 481-495, available at: https:// doi.org/10.1002/(SICI)1099-131X(1998090)17:5/6<481::AID-FOR709>3.0.CO;2-Q

Agerschou, H. and Lundgren, H. (1993), Planning and Design of Ports and Marine Terminals, John Wiley and Sons, Chichester.

Allen, G. and Fildes, R. (2001), "Econometric forecasting", in Armstrong, J.S. (Ed.), Principles of Forecasting, Kluwer Academic Publishers, Norwell, MA.

Anonym, J.C. (1996), "Market analysis: in-terminal handling equipment", Containerization Internationalisation, Vol. 4, pp. 212-219.

Armstrong, J. and Brodie, R. (1999), "Forecasting for marketing”, in Hooley, G. and Hussey, M. (Eds), Quantitative Methods in Marketing, 2nd ed., London International Thompson Business Press, London, pp. 92-119.

Armstrong, J.S. (2001), A Handbook for Researchers and Practitioners, Kluwer Academic Publishers, Norwell, MA.

Atkins, W.H. (1993), “Modern marine terminal operations and management”, Port of Oakland, USA. 
MABR

3,1

Avery, P. (1999), The Future of Container Handling Technology and Cargo System, IIR Publications, London.

Bank of Thailand (2016), available at: www.bot.or.th

Beskovnik, B. (2008), "Measuring and increasing the productivity model on maritime container terminals", Scientific Journal of Maritime Research, Vol. 22 No. 2, pp. 171-183.

Chen, S.-H. and Chen, J.-N. (2010), "Forecasting container throughputs at ports using genetic programming", Expert Systems with Applications, Vol. 37 No. 3, pp. 2054-2058.

Chou, C.-C., Chu, C.-W. and Liang, G.-S. (2008), "A modified regression model for forecasting the volume of Taiwan's import containers", Mathematical and Computer Modelling, Vol. 47 Nos 9/10, pp. 797-807.

Chu, C.-Y. and Huang, W.-C. (2005), "Determining container terminal capacity on the basis of an adopted yard handling system”, Transport Review, Vol. 25 No. 2, pp. 181-199.

EU (2004), "Directive 2004/ 26/EC of the European Parliament and of the Council of 21 April 2004 amending Directive 97/68/EC on the approximation of the laws of the member states relating to measures against the emission of gaseous and particulate pollutants from internal combustion engines to be installed in non-road mobile machinery", Official Journal of the European Union, L 146, Vol. 47 (April), pp. 1-107.

Fung, M.K. (2002), "Forecasting Hong Kong's container throughput: an error-correction model”, Journal of Forecasting, Vol. 21, pp. 69-80.

Gosasang, V., Chandraprakaikul, W. and Kiattisin, S. (2011), "A comparison of traditional and neural networks forecasting techniques for container throughput at Bangkok Port", The Asian Journal of Shipping and Logistics, Vol. 27 No. 3, pp. 463-482, available at: https://doi.org/10.1016/S20925212(11)80022-2

Guo, X., Huang, S.Y., Hsu, W.J. and Low, M.Y.H. (2011), "Dynamic yard crane dispatching in container terminals with predicted vehicle arrival information", Advanced Engineering Informatics, Vol. 25 No. 3, pp. 472-484.

Holguín-Veras, J. and Jara-Díaz, S. (2006), "Preliminary insights into optimal pricing and space allocation at intermodal terminals with elastic arrivals and capacity constraint", Networks and Spatial Economics, Vol. 6 No. 1, pp. 25-38.

Hui, E., Seabrooke, W. and Wong, G. (2004), "Forecasting cargo throughput for the port of Hong Kong: error correction model approach", Journal of Urban Planning and Development, Vol. 130 No. 4, pp. 195-203.

Kemme, N. (2012), "Effects of storage block layout and automated yard cranes systems on the performance of Seaport container terminals", OR Spectrum, Vol. 34 No. 3, pp. 563-591.

Li, M.K. and Yip, T.L. (2013), "Joint planning for yard storage space and home berths in container terminals", International Journal of Production Research, Vol. 51, pp. 3143-3155, available at: https://doi.org/10.1080/00207543.2012.760852

Makridakis, S., Whellwright, S.C. and Hynman, R.J. (1998), Forecasting: Methods and Applications, 3rd ed., John Wiley \& Son, Hoboken, NJ.

Meermans, P.J.M. and Dekker, R. (2001), "Operations research supports container handling", Econometric Institute Research Papers, No EI 2001-22, Erasmus University Rotterdam, Erasmus School of Economics (ESE), Econometric Institute.

Mills, R.W. (1994), Finance, Strategy and Strategic Value Analysis: Linking Two Key, Business Issues, Butler and Tanner, Frome.

Ministry of the Interior, and the Energy Policy and Planning Office (2016), available at: www.eppo. go.th

Moniruzzaman, M.D., Toy, M.M. and Hassen, A.B.M.R. (2011), "The export supply model of Bangladesh: an application of cointegration and vector error correction approaches", International Journal of Economics and Financial Issues, Vol. 1 No. 4, pp. 163-171. 
Ng, W.C. and Mak, K.L. (2005), "An effective heuristic for scheduling a yard crane to handle jobs with different ready times", Engineering Optimization, Vol. 37 No. 8, pp. 867-877.

Niwari, A. (2004), "Container terminal expansion to build capacity: a case study", Master thesis, Erasmus University Rotterdam, Rotterdam.

Office of the National Economic and Social Development Board (2016), available at: www.nesdb.go.th

Peng, W.-Y. and Chu, C.-W. (2009), "A comparison of univariate methods for forecasting container throughput volumes", Mathematical and Computer Modelling, Vol. 50 Nos 7/8, pp. 1045-1057.

Petering, M.E.H. (2009), "Effect of block width and storage yard layout on marine container terminal performance", Transportation Research Part E: Logistics and Transport Review, Vol. 45 No. 4, pp. 591-610.

Petering, M.E.H. and Murty, K.G. (2009), "Effect of block length and yard crane deployment systems on overall performance at a Seaport container transshipment terminal", Computers and Operations Research, Vol. 36 No. 5, pp. 1711-1725.

Port of Rotterdam (2014), available at: www.portofrotterdam.com

Putten, M.V. (2005), "Increasing yard deployment efficiency at APM terminals Rotterdam”, Master thesis, Technische University Eindhoven, Eindhoven.

Seo, Y.-J. and Park, J.S. (2016), "The estimation of minimum efficient scale of the port industry", Transport Policy, Vol. 49, pp. 168-175.

Speer, U., John, G. and Fisher, K. (2011), "Scheduling yard cranes considering crane interference”, in Böse, J.W., Hu, H., Jahn, C., Shi, X., Stahlbock, R. and Voß, S. (Eds), Computational Logistics, ICCL 2011, LNCS 6971, Springer, Berlin Heidelberg, pp. 321-340.

Syafi'I (2006), "Multivariate autoregressive model for forecasting the demand of container throughput in Indonesia”, Media Teknik Sipil, pp. 129-134.

UNCTAD (2016), "Review of maritime transport 2014", UNCTAD, United Nations Publication. UNCTAD/RMT/2014, available at: www.unctad.org/en/docs/rmt2014_en.pdf (accessed 14 April 2010).

Wiegmans, B. (2003), "Performance conditions for container terminals", Dissertation, Vrije University Amsterdam, Amsterdam.

Wiese, J., Suhl, L. and Kliewer, N. (2011), "Planning container terminal layouts considering equipment types and storage block design", in Böse, J. (Ed.), Handbook of Terminal Planning, Chapter 12, Springer, New York, NY, pp. 219-245.

World Bank (2016), available at: www.worldbank.org

Yip, T.L., Sun, X.Y. and Liu, J.J. (2011), "Group and individual heterogeneity in a stochastic frontier model: container terminal operators”, European Journal of Operational Research, Vol. 213 No. 3, pp. 517-525, available at: https://doi.org/10.1016/j.ejor.2011.03.040

Zondag, B., Bucci, P., Gutzkow, P. and De Jong, G. (2010), "Port competition modeling including maritime, port and hinterland characteristics", Maritime Policy and Management, Vol. 37 No. 3, pp. 179-194.

\section{Corresponding author}

Veerachai Gosasang can be contacted at: veerag1968@hotmail.com

For instructions on how to order reprints of this article, please visit our website:

www.emeraldgrouppublishing.com/licensing/reprints.htm

Or contact us for further details: permissions@emeraldinsight.com 